\title{
Estrogen lowers triglyceride via regulating hepatic APOA5 expression
}

\author{
Fei Luo, Yuan Guo, Gui-yun Ruan, Ran Peng and Xiang-ping Li
}

\begin{abstract}
Estrogen had been found to be negatively associated with serum triglyceride (TG) levels. Apolipoprotein A5 (APOA5), a novel member of apolipoprotein family, was reported to have a strong ability to decrease serum concentrations of TG. Clinical data found concentrations of APOA5 were higher in woman than that in men, and the negative relationship between APOA5 and TG levels was more significant in woman. These suggests APOA5 may involve in estrogen actions. Therefore, we hypothesize estrogen up-regulates serum concentrations of APOA5 and subsequently decreases serum TG levels. We will design the following experiments to test this hypothesis. (1) We will treat wild and APOA5-defeted ovariectomized hamster with or without estrogen to examine if estrogen could up-regulate concentrations of APOA5 and decrease TG levels. (2) We will treat HepG2 cells with estrogen and investigate the possible mechanisms.
\end{abstract}

Keywords: Estrogen, Triglyceride, GPR30, APOA5

\section{Background}

Estrogen, an essential female hormone, is critical to modulating lipid metabolism [1]. Decline in estrogen concentrations was linked to dyslipidemia in peri- and post-menopausal women, including increased serum triglyceride (TG) levels [2, 3]. Guo et al. [2] reported that TG levels of postmenopausal women were significant higher than that of pre-menopausal women $(1.73 \pm 0.98$ vs $1.07 \pm 0.63 \mathrm{mmol} / \mathrm{L}, P<0.05)$. Whitcroft et al. [4] reported that transdermal estradiol treatment for postmenopausal women could lower serum TG levels by about 16.4\% $(P<0.01)$. Pulchinelli et al. [5] found that estrogen replacement therapy statistically reduced TG levels of hysterectomized women. A meta-analyzed further confirmed a modest effect of transdermal estradiol treatment on decrease of serum TG levels [6]. Recently, estrogen was confirmed to reduce TG levels in in mice hepatology [7]. Therefore, estrogen is important in maintaining TG homeostasis, but the underlying mechanisms remain to be elucidated.

Apolipoprotein A5 (APOA5) was a novel member of apolipoprotein family and mainly secreted by liver,

\footnotetext{
* Correspondence: lixp0040@sina.com

Department of Cardiovascular Medicine, The Second Xiangya Hospital,

Central South University, 139 Middle Renmin Road, Changsha, Hunan

410011, People's Republic of China
}

(c) The Author(s). 2017 Open Access This article is distributed under the terms of the Creative Commons Attribution 4.0 International License (http://creativecommons.org/licenses/by/4.0/), which permits unrestricted use, distribution, and reproduction in any medium, provided you give appropriate credit to the original author(s) and the source, provide a link to the Creative Commons license, and indicate if changes were made. The Creative Commons Public Domain Dedication waiver (http://creativecommons.org/publicdomain/zero/1.0/) applies to the data made available in this article, unless otherwise stated.

which possessed a strong ability of decreasing serum TG levels [8]. APOA5 genetic variants were associated with increased TG levels in humans, and human APOA5 transgenic mice showed a decrease in plasma triglyceride concentrations to one-third of those in control mice [9-12]. Moreover, data was not only reported a negative correlation between APOA5 and TG levels, but also indicated the two indices changing more significant in female. Zhao et al. [13] reported serum concentrations of APOA5 were negatively and predominantly correlated with TG levels in female $(r=-0.496, P=0.001)$ but not in male $(r=0.054, P=0.709)$. Ishihara et al. [14] observed serum concentrations of APOA5 in premenopausal female were higher than that in male of the similar age. It suggests estrogen might up-regulate APOA5 expression, and thereby decrease TG levels.

\section{Presentation of the hypothesis}

The estrogen actions had been traditionally attributed to the classical nuclear estrogen receptors (ERs), ER $\alpha$ and ER $\beta$. More recently, the $G$ protein-coupled receptor 30 (GPR30), also known as G protein-coupled estrogen receptor 1, was claimed as an essential estrogen receptor [15]. It was also identified to be closely related to lipid metabolism. The Gpr30 knockout mice exhibited an abnormal lipid profile with an approximately $71 \%$ increase in triglyceride 
levels [16, 17]. Consistently, Zucchetti et al. [18] demonstrated that GPR30 was essential for estrogen exerting its function in liver of altering canalicular transporter function and localization. This indicates that estrogen regulates TG at least in part through GPR30.

Peroxisome proliferator-activated receptor $\alpha(\mathrm{PPAR} \alpha)$ was a number of the nuclear receptor superfamily and directly regulated lipid transport, storage and metabolism. PPAR $\alpha$ was also found to up-regulate APOA5 gene expression and a functional PPAR $\alpha$ response element in the proximal $A P O A 5$ promoter was detected by using deletion and mutagenesis analyses [19]. Furthermore, it was identified that hepatocyte nuclear factor- $4 \alpha$ (HNF- $4 \alpha)$ was a highly conserved member of the nuclear receptor superfamily, which was initially identified as a transcriptional factor required for liver-specific gene expression, and it was also critical in regulating the transcription of genes involved in glucose and lipid metabolism including APOA5 [20]. Intriguingly, previous study reported that HNF-4 $\alpha$ and PPAR $\alpha$ expression could be activated by hepatic protein kinase A (PKA) pathway [21]. More interestingly, it was reported that hepatic GPR30 combined with estrogen and in turn exerted its function by activating PKA pathway [18]. Thus, we speculated estrogen combined with GPR30 and consequently activated the hepatocyte PKA signaling pathway, which enhanced PPAR $\alpha$ and HNF4 $\alpha$ expression in liver and thereby increasing hepatic APOA5 expression and finally decreased serum TG levels.

Therefore, we hypothesize estrogen up-regulates APOA5 expression to reduce plasma TG levels via combination with GPR30 with an aim of providing more evidence for exploring the TG lowing effect of estrogen and insight into novel therapeutic target.

\section{Testing the hypothesis}

We will design some experiments to test this hypothesis. (1) We will treat wild ovariectomized hamster with or without estradiol to examine if estradiol could up-regulate APOA5 and decrease TG levels. Then we will evaluate whether the deletion of APOA5 could abort the decrease effects of estradiol. (2) We will treat HepG2 cells with estradiol and detect the concentrations of APOA5 in and out cells. We will also use GPR30 receptor antagonist to exam if this effect was induced by GPR30.

\section{Abbreviations \\ APOA5: Apolipoprotein A5; ERs: Estrogen receptors; GPR30: G protein-coupled receptor 30; HNF-4a: Hepatocyte nuclear factor-4a; PKA: Protein kinase A; PPARa: Peroxisome proliferator-activated receptor $a ;$ TG: Triglyceride}

\section{Acknowledgements}

None.

\section{Funding}

This work was supported by the grants from the National Natural Science Foundation of China (No.31670816) and Fundamental Research Funds for the Central Universities of Central South University (No.2016zzts542).
Availability of data and materials

Not applicable.

\section{Authors' contributions}

$X L$ conceived the idea; FL performed experiments and wrote the manuscript; $F L, Y G, G R$ and RP collected and read the literature; $X L$ read through and corrected the manuscript. All authors read and approved the final manuscript.

\section{Competing interests}

The authors declare that they have no competing interests.

\section{Consent for publication}

Not applicable.

\section{Publisher's Note}

Springer Nature remains neutral with regard to jurisdictional claims in published maps and institutional affiliations.

Received: 6 August 2016 Accepted: 28 March 2017

Published online: 04 April 2017

\section{Reference}

1. Barton M. Cholesterol and atherosclerosis: modulation by oestrogen. Curr Opin Lipidol. 2013;24:214-20.

2. Guo W, Fu J, Chen X, et al. The effects of estrogen on serum level and hepatocyte expression of PCSK9. Metabolism. 2015;64:554-60.

3. Korljan B, Bagatin J, Kokic S, Berovic Matulic N, Barsic Ostojic S, Dekovic A. The impact of hormone replacement therapy on metabolic syndrome components in perimenopausal women. Med Hypotheses. 2010;74:162-3.

4. Whitcroft SI, Crook D, Marsh MS, Ellerington MC, Whitehead MI, Stevenson JC. Long-term effects of oral and transdermal hormone replacement therapies on serum lipid and lipoprotein concentrations. Obstet Gynecol. 1994;84:222-6.

5. Pulchinelli Jr A, Costa AM, de Carvalho CV, et al. Positive association of the hepatic lipase gene polymorphism c.514C > T with estrogen replacement therapy response. Lipids Health Dis. 2011;10:197.

6. Godsland IF. Effects of postmenopausal hormone replacement therapy on lipid, lipoprotein, and apolipoprotein (a) concentrations: analysis of studies published from 1974-2000. Fertil Steril. 2001;75:898-915.

7. Han SI, Komatsu Y, Murayama A, et al. Estrogen Receptor Ligands Ameliorate Fatty Liver Through a Nonclassical Estrogen Receptor/Liver X Receptor Pathway in Mice. Hepatology. 2014;59:1791-802.

8. Nilsson SK, Heeren J, Olivecrona G, Merkel M. Apolipoprotein A-V; a potent triglyceride reducer. Atherosclerosis. 2011;219:15-21.

9. Zhu WF, Wang $C L$, Liang $L$, et al. Triglyceride-raising APOA5 genetic variants are associated with obesity and non-HDL-C in Chinese children and adolescents. Lipids Health Dis. 2014;13:93.

10. Ouatou S, Ajjemami M, Charoute $H$, et al. Association of APOA5 rs662799 and rs3135506 polymorphisms with arterial hypertension in Moroccan patients. Lipids Health Dis. 2014;13:60.

11. Johansen $C T$, Wang J, Lanktree MB, et al. Excess of rare variants in genes identified by genome-wide association study of hypertriglyceridemia. Nat Genet. 2010:42:684-7.

12. Pennacchio LA, Olivier M, Hubacek JA, et al. An apolipoprotein influencing triglycerides in humans and mice revealed by comparative sequencing. Science. 2001;294:169-73.

13. Zhao SP, Hu S, Li J, et al. Association of human serum apolipoprotein A5 with lipid profiles affected by gender. Clin Chim Acta. 2007;376:68-71.

14. Ishihara M, Kujiraoka T, Iwasaki T, et al. A sandwich enzyme-linked immunosorbent assay for human plasma apolipoprotein A-V concentration. J Lipid Res. 2005;46:2015-22.

15. Prossnitz ER, Barton M. The G-protein-coupled estrogen receptor GPER in health and disease. Nat Rev Endocrinol. 2011;7:715-26.

16. Sharma G, Hu C, Brigman JL, Zhu G, Hathaway HJ, Prossnitz ER. GPER deficiency in male mice results in insulin resistance, dyslipidemia, and a proinflammatory state. Endocrinology. 2013;154:4136-45.

17. Sharma G, Prossnitz ER. GPER/GPR30 Knockout Mice: Effects of GPER on Metabolism. Methods Mol Biol. 2016:1366:489-502.

18. Zucchetti $A E$, Barosso IR, Boaglio AC, et al. G-protein-coupled receptor 30/ adenylyl cyclase/protein kinase A pathway is involved in estradiol 17ss-Dglucuronide-induced cholestasis. Hepatology. 2014;59:1016-29. 
19. Prieur X, Coste H, Rodriguez JC. The human apolipoprotein AV gene is regulated by peroxisome proliferator-activated receptor-alpha and contains a novel farnesoid X-activated receptor response element. J Biol Chem. 2003;278:25468-80.

20. Prieur X, Schaap FG, Coste H, Rodriguez JC. Hepatocyte nuclear factor4alpha regulates the human apolipoprotein AV gene: identification of a novel response element and involvement in the control by peroxisome proliferator-activated receptor-gamma coactivator-1alpha, AMP-activated protein kinase, and mitogen-activated protein kinase pathway. Mol Endocrinol. 2005;19:3107-25.

21. Konstandi M, Shah YM, Matsubara T, Gonzalez FJ. Role of PPARa and HNF4a in Stress-Mediated Alterations in Lipid Homeostasis. PLoS One. 2013:8:e70675.

Submit your next manuscript to BioMed Central and we will help you at every step:

- We accept pre-submission inquiries

- Our selector tool helps you to find the most relevant journal

- We provide round the clock customer support

- Convenient online submission

- Thorough peer review

- Inclusion in PubMed and all major indexing services

- Maximum visibility for your research

Submit your manuscript at www.biomedcentral.com/submit
) Biomed Central 